\title{
Chapter 6 \\ Returning for (Dis)Integration \\ in the Labour Market? The Careers \\ of Labour Migrants Returning to Poland \\ from the United Kingdom
}

\author{
Mateusz Karolak
}

\subsection{Introduction ${ }^{1}$}

Since the 2004 and 2007 enlargements of the European Union (EU), return migration from Western to Eastern EU member-states has become a relevant topic on political and research agendas. The new migration patterns and the increasing number of returnees raised questions regarding migrants' (re)integration into their society of origin. Although return migration occurs in supposedly more integration-friendly circumstances - the returnees do not lack the foundations of integration such as rights and citizenship, nor facilitators such as language and other cultural knowledge (Ager and Strang 2008) - some returnees still encounter problems in the core domains of integration, including those crucial for their social position and integration on the labour market. Existing research points out that, regarding the labour market situation, the population of returnees is very heterogeneous and its structure resembles that of the society of origin (except for the excessive growth in the number of self-employed among the returnees). It openly challenges the discourse of the universal profitability of labour mobility and return. The so-called 'triple win scenario' (Sinatti 2015) assumes that migrants, after fulfilling the temporary demand for labour in the receiving country, return to their country of origin and work, making efficient use of the skills and knowledge accumulated abroad (cf. Samuk 2020). In this way, they help to solve the problems of their country's economy (e.g. filling the demand for labour, easing skills shortages and boosting the innovation level) and demography.

\footnotetext{
${ }^{1}$ The work on this chapter was possible thanks to a doctoral scholarship received from the National Science Center Poland (NCN) (UMO-2016/20/T/HS6/00479).
}

\author{
M. Karolak ( $ه)$ \\ University of Wroclaw, Wrocław, Poland \\ e-mail: mateusz.karolak@uwr.edu.pl
}


As observed by various sociologists (e.g. Bauman 2000; Sennett 1998; Urry 2000), spatial mobility became perceived in advanced economies as a key element of a successful occupational career. Spatial flexibility - one of the critical dimensions of the transition from a Fordist to a post-Fordist economy - went from being just an option into a social expectation deriving from the logic of late capitalism. As pointed out by Jesse Potter (2015, p. 7): 'The primary attribute of successful new economy workers is their mobile and flexible approach to their productive lives'. Jane Wills et al. (2010, p. 6) observe that, in the eyes of many, the migrant became 'the world's paradigmatic worker', praised for their hard work, ability to adjust to the market and readiness to move once they are no longer needed. Thomas Faist (2013, p. 1644), in turn, notes that

[t]his shift towards a positive evaluation of movement is deeply problematic because it usually does not reflect underlying trends that aim to build a flexible, docile and politically abstinent global workforce - processes sometimes discussed under the label 'neoliberalism'.

The discrepancy between the praising discourse of mobility and the much more ambiguous realities experienced by returning labour migrants has still not been sufficiently explained and the mechanisms contributing to both the returnees' integration and their disintegration require further examination. Therefore the main task of this chapter is to contribute to this emerging discussion and to analyse the practices and labour market (dis)integration paths of intra-EU return migrants, taking as an example the experiences of Polish post-accession migrants returning to Poland from the United Kingdom.

On a theoretical level, the chapter argues that, in the context of the growing precarisation of work (Standing 2011), it is necessary to rethink the rigid integrationexclusion discourse, which considers as integrated into labour market all those in employment, regardless of its quality and stability.

Instead, drawing inspiration from labour-market segmentation theories, it is argued that tracing the course of migrants' occupational careers on the multisegmented labour market enables us to go beyond a dichotomous understanding of labour market integration and to account for the varieties of change in employment patterns and condtions. In this way, this chapter reveals the labour-related layer of the politics of (dis)integration.

My case study of return migration from the UK to Poland will serve as a specific laboratory for looking at ongoing global changes. Firstly, intra-EU mobility, with its East-West-East migration, is a significant part of the global division of labour, with all its inequalities (Favell 2008; Wills et al. 2010). Secondly, the abolition of national borders within the Schengen area might be seen not so much as a sign of borders' disappearance but, rather, of their proliferation and displacement into other than spatial dimensions of life (Mezzadra and Neilson 2013). These changes brought out new forms of intra-EU labour mobility control, well described by the theory of governmentality (Foucault 2008; Mezzadra and Neilson 2013). The traditional control exercised externally, usually by legal means and state forces (e.g. visas, temporary work schemes, employer-sponsored migration, physical borders), has been 
gradually replaced by the emergence of mobile subjects who deeply internalise the rules of the market game and whose footloose mobility becomes functional to the workings of contemporary capitalism (cf. Foucault 2008, p. 230).

The chapter is structured as followed: first, I shed light on the specificity of intraEU movement and post-accession migration between Poland and the UK. Second, I examine the state policies, or lack thereof, with regard to return migration. Next, I look at the pitfals of a simplified understanding of labour market integration and introduce the theory of multi-segmented labour markets. Finally, after the methodological note, the four main types of returning migrants' transitions between labour markets are presented.

\subsection{Migration and Return Migration - The Case of Poland and the UK}

The opening of EU borders in 2004 and 2007 and the gradual withdrawing of labour market restrictions for EU citizens affected the whole of Europe. As summed up by Drinkwater and Garapich (2013, p. 2), 'EU enlargement resulted in the biggest demographic change in Europe since the devastation and flux experienced at the end of the Second World War (...), with the UK at the centre of that movement'.

At the end of 2017, of the 2.5 million Poles living abroad, 2.1 million resided in the EU. In the UK, the number of Poles skyrocketed from 24,000 in 2004 to 690,000 in 2007 and reached 793,000 by 2017 (GUS 2018). Simultaneously, the number of Polish returnees from the UK between 2004 and 2014 is estimated to be at least 587,000 (Karolak 2016).

Besides the unexpected growth in migration flows, patterns of migration have also changed. In addition to the settlement, circular or incomplete forms of migrations observed in the 1990s (Okólski 2001), researchers noted the importance of a new phenomenon known as 'liquid migration' (Engbersen et al. 2010 Engbersen and Snel 2013). It is characterised by individualisation, lesser attachment to the family and multidimensional temporariness, leading to an increasing number of returnees. '[Liquid] migrants try their luck in new and multiple countries of destination, benefiting from open borders and labour markets' (Engbersen et al. 2013, pp. 960-961). The 'liquid migrants' were clearly present in the post-2004 EU accession migration from Poland to the UK. As shown by John Eade and his collaborators (2007), the undecided migrants - called in the study the 'searchers' - accounted for $42 \%$ of all Polish migrants in the UK.

For $73 \%$ of Poles, work was the main reason for their emigration (GUS 2013). However, as shown in various qualitative studies (e.g. Grabowska 2016a; Kaźmierska et al. 2011; Polkowski 2017), non-economic reasons were equally important for some migrants. For young Central and Eastern Europeans, migration is often treated as a relevant life experience and rite of passage into adulthood (Grabowska 2016a) the journey which teaches cultural independence and offers a chance to gain 
economic independence, seen by young people as unachievable in their country of origin (Polkowski 2017). Finally, the Polish National Census (GUS 2013, p. 70) showed that $50 \%$ of Polish citizens abroad plan to return 1 day to Poland, whereas $38 \%$ were still undecided and only $12 \%$ did not want to return at all. However, initial declarations about migration plans usually do not correspond with the future course of migration - as was shown in the case of Poles in the UK (Drinkwater and Garapich 2013).

The existing research provides mixed evidence regarding the labour market situation of those who eventually decide to return. Moreover, there is, unfortunately, a lack of representative data regarding Polish return migrants from the UK. Nevertheless, it has been suggested that, thus far, migratory experience is not perceived as an advantage in the Polish labour market, in contrast to a knowledge of foreign languages and other soft skills (Kaczmarczyk and Lesińska 2012, p. 31).

After analysis of the 1999-2009 Labour Force Survey, Anacka and Fihel (2013, p. 68) conclude that: '(...) in comparison with non-migrants, migrants are clearly less likely to find employment in Poland'. How, then can we account for these differences and explain them in the context of individual biographies? Do returnees face problems with integration and what quality of employment can they expect? Which role do the migration episode(s) and state's policy play in shaping returnees' career paths?

Before I attempt to answer these questions, it is, however, necessary to analyse the very concept of integration, with a particular focus on integration into the labour market which - as I argue - requires re-conceptualisation in times of a growing precarisation of labour and expanding inequalities among employees.

\subsection{Return Migrants' (Dis)Integration, the Role of the State and the Conceptual Framework}

The conceptual framework of the core domains of integration introduced by Alastair Ager and Alison Strang (2008) proved helpful in understanding the theoretical challenge posed by the concept of returning migrants' integration. Ager and Strang proposed to differentiate between foundations (rights and citizenship), facilitators (language and cultural knowledge), social connection (social bridges, bonds and links) as well as markers and means of integration such as employment, housing, education and health (for a more detailed discussion of Ager and Strang's integration framework see the chapter by Tina Magazzini in this volume. From this perspective, returning migrants do not lack the essential foundations of integration - citizenship and rights. Furthermore, almost all of them dispose of the critical facilitators of integration which are language and cultural knowledge.

When it comes to other domains of integration identified by Ager and Strang, the situation of returning migrants, including the first generation, is more ambiguous. They might lack safety and stability which, in conjunction with weaker social con- 
nections, may have an impact on their life situation in the spheres of employment, housing, education and health.

The state, with its institutions, could be an important actor in the process of creating both favourable and unfavourable conditions for returnees' integration. Its actual role depends, however, on the particular constellation of return mobility. The state can either treat returnees on an equal footing with all other citizens, providing them with the same access to institutional support regardless of their migration experience or it can recognise returning migrants as a separate group of citizens in need of support, drawing up particular policies for such situations. In this case, policies for returnees could take either a reactive or an active form (Lesińska 2013). The former is merely a state response to already existing processes of return which have occurred independently of the state's actions. The latter, in turn, aims to 'encourage nationals to return. When returns are recognised as a positive and desirable process (...), then policy-makers act to stimulate migrants' decision to return and to facilitate the process of coming back to the home country' (Ibid., p. 79). What is important to note is that active policies for returnees are often selective and aimed at bringing back a particular occupational group of migrants who are perceived as valuable for society (e.g. schemes encouraging the return of doctors, entrepreneurs or scholars); however, such a move might be treated as a symptom of the increasingly utilitarian approach of the state towards its citizens (Sahraoui et al. 2018). Whereas encouraging return migration often appears on political agendas and in discourses, support for the integration of returning migrants is less often perceived as an issue of state policy.

In Poland, an evolution of state policies addressing Poles abroad is observable. Just after the EU enlargement of 2004, the state initiated an educational campaign focusing on the rights of Polish labour migrants aborad and aimed at 'protecting Polish citizens against dangers and threats related to the often unprepared labour emigration' (Lesińska 2013, p. 84). Among many activities, the state planned not only to improve the image of Poland among potential returnees but also to introduce tax relief, reduce their social insurance and pension contribution rate and organise job fairs abroad, designed to match employers with potential employees and ensure that the latter can return directly into the Polish labour market.

These policies, however, were never implemented due to the change of government in 2008, which shifted towards a reactive type of policy. It was assumed that 'the main aim of the State policy is not to influence individual migrants' decisions to return, but to provide them with a tool enabling them to make a rational choice' (Lesińska 2013, p. 85). The main instrument disseminated via various information channels was potentially helpful in organising migrants' return (e.g. how to avoid double taxation or how to change a child's school).

Crucially, reintegration, in these policies, was understood as the mere fact of being active in the labour market, which points to the broader phenomenon of equating labour-market integration with finding employment. Therefore, in the next section, I highlight the limitations of the debate on labour market integration and propose to examine returning labour migrants' experiences not through the binary opposition of integration-exclusion but, rather, through the theoretical lens of the 
multi-segmented labour market and the concept of (dis)integration, as proposed in the introduction to this volume (Collyer et al. 2020). I argue that the combination of theories of the multi-segmented labour market and the sociological concept of career helps to account for the diversity of returnees' experiences of (dis)integration.

\subsection{Integration, Inclusion and Exclusion and Their Limitations}

Despite some advantages in explaining inequalities, the dominant approaches to integration have several pitfalls. First, they implicitly assume and generalise a particular view on society and its desirable values. Beyond each approach about integration, there is an underlying moral meta-narration. It is assumed that 'social inclusion or integration, as the opposite of social exclusion, is inherently good and desirable' (Fangen et al. 2011, p. 2). Such an assumption, in turn, leads to a situation whereby attempts to integrate those perceived as socially excluded might turn out to be 'problematic, disempowering or inequitable' (2011, p. 2). To be more specific, the contemporary European policies of integration tend to narrow themselves to the issue of employment, reflecting the shift from welfare to 'workfare' policies, as shown, for example, by Sophie Hinger (2020).

Ruth Levitas (2005) argues that, despite differences in understanding what it means to be socially excluded or included (thus, integrated), the underlying assumptions of integration discourses stem from Durkheim's understanding of society as organised around organic solidarity, with cohesion as its natural state (Durkheim 1997 [1893]). Both Durkheim and dominant discourses of integration share the assumption that 'the individual identity as well as individual integration into society is primarily constituted through work' (Levitas 2005, p. 181). Importantly, in both cases, work is understood narrowly as paid employment. Such a narrow understanding of work leads to the situation in which all those who exercise unpaid reproductive work are left aside or labelled as reluctant to work.

Second, the dichotomous view imposed by the basic opposition between the integrated and the excluded oversimplifies a very complex social reality and obscures the differences between those perceived as integrated. This has one further connotation, namely the language of exclusion shifts away from sight the class perspective and undermines the divergent, or sometimes even conflicting, interests of various groups.

Last but not least, the discussed approaches essentialise social reality, skipping the relational and processual aspects of the social position. This leads to the overlooking of both the life trajectories of individuals and the dynamic structural changes (e.g. in the employment patterns) which might shift the social position of entire groups.

From this perspective, exploring returning migrants' experiences in terms of traditionally understood labour market integration would bring few results, as the analysis would boil down to the question of whether the returnee is employed or not. Therefore, bearing in mind the above-mentioned limitations of the integration 
discourse, yet acknowledging the possibility of returning migrants encountering various disadvantages on the labour market, the following issue arises: How should we approach and map the returnees' labour experiences without imposing moral meta-narration, ignoring the spectre of individual and group (class) inequalities as well as essentialising?

In this chapter I propose to look at the returnees' labour market (dis)integration through the lense of multi-segemented labour market theory (Loveridge and Mok 1979). According to this theory, the labour market is not homogenous and its model could be built around two continuous axes - the vertical or 'social axis' covers the field of industrial relations and shows the 'differentiation of jobs and people in terms of their rewards (and punishments), working conditions, responsibility, autonomy and job security' (1979, p. 123) and the horizontal or 'bureaucratic'/'technical' axis reflects the differences in skills, training required and place in the hierarchy. In this way, by underlining the varieties of employment (for example, starting with the bank manager in a secure and very well paid job, through the less secure but still well paid free-lancer, to the precarious waiter on the zero-hours contract) this model reflects the continuum of returning migrants' positions not only within but also outside the labour market.

After my methodological note, the last sections are devoted to the application of the proposed theoretical framework and the exploration of differences in returning migrants' transitions between the British and Polish labour markets.

\subsection{Research Design and Methodology}

Following the methodologies established in the biographical tradition (Schütze 2016), 30 biographical narrative interviews with Polish returnees from the UK and with re-emigrants to the UK were carried out between November 2013 and June 2016, as part of my $\mathrm{PhD}$ research. The interviews included biographical issues, explored the motives and motivations for migration, return and re-emigration, and addressed returnees' post-migration experiences on the labour market.

The choice of the informants, as well as the analysis of the collected interviews, followed the procedures of grounded theory methodology or GTM (Glaser and Strauss 1967). The fieldwork began with a purposive sampling of long-term labour migrants who had worked in the UK for at least 1 year and who, after their return, lived in Poland for at least 6 months, irrespective of their reasons for migration, return and re-emigration (if this occurred). The relatively broad criteria of the initial sample were aimed at grasping the variety of labour migrants motivations for return. It was also assumed that irrespective of the explicitly declared reason for return the biographical narrative interviews could also reveal the configurations of individual and structural factors, which influence the process of return and subsequent returnees' situation in the labour market.

The respondents were initially recruited through snowball sampling, mailings and migrant Internet forums. At the first stage of the fieldwork, I reached mainly 
migrants with secondary or higher education, younger than 35 years of age. Over time, following the prescriptions of the GTM, I began comparison and open coding of the already conducted interviews, while still collecting new narratives. At this stage of the research, the sampling became theoretical and aimed at saturating the themes and categories emerging from the initial analysis. Since the objective of the theoretical sampling lies in 'simultaneous maximization and minimization of both differences and similarities of data that bear on categories being studied' (Glaser and Strauss 1967, p. 55) I interviewed migrants with lower education levels and/or older than 35. Moreover, initially I talked to people who either returned to Lower Silesia region of Poland or after return left Poland for Scotland, yet over time the sample was extended to migrants living in Warsaw and London, the capitals that attract return migrants (Anacka and Fihel 2013) and, as it turned out in a course of the research, some of the double return migrants.

Of the interviewees, 16 were women and 14 were men. The biggest group of the informants (16) was between 25 and 30 years old; 4 of them were under 25 years old and the remaining 10 were over 30 years old. The majority of the informants (23) had at the moment of the interview (not necessarily during migration) some form of tertiary education, that is: 16 informants had obtained a Master's degree (13 MA and $3 \mathrm{MSc}$ ) and 6 informants held a Bachelor's degree (5 BA, and $1 \mathrm{BSc}$ ). Moreover, 6 informants had completed secondary education (3 general and 3 technical) and 2 others had an elementary level of education.

It needs to be underlined that 'Unlike statistical sampling, theoretical sampling [does] not aim at statistical representativeness, but at the development of an empirically grounded understanding of the substantive field of study.' (Mrozowicki 2011, p. 88) Thus the research results presented in the next section, although not representative, reveal the variety of returnees' experiences in the labour market as well as some of the mechanisms contributing to the returning migrants' disintegration.

\subsection{Returning Migrants' Labour Market Transitions Shaped by the Politics of (Dis)Integration}

Analysis of the interview narratives revealed four main types of return migrant transitions between the British and the Polish labour markets - the effortless, the unforeseen, the failed and the postponed.

\subsubsection{The Effortless Transition}

The first type, the effortless transition between the labour markets, describes the situation in which returning migrants not only had no trouble finding employment in Poland but also worked in accordance with their expectations. Understandably, this was typically the case of returnees keen to enhance their career and who found 
an interesting job in Poland before leaving the UK and only then decided to move back there. However, crucial for this type of transition were structural circumstances enabling an efficient use of migrants' capital - such as a diploma from a British university - which, by some employers, was perceived as an advantage and which singled some migrants out, as it did for Patrycja:

It seems to me that, as I had a university degree from the UK..., on not such a typical field of study in Poland, it really mattered and it meant that I even got the chance of a job interview, and in the end I got this job. Well, my boss later liked to sell it so nicely that the team in our organisation consists of people from all over Europe. Well, because I came from Scotland, as later he was putting it so nicely, he liked to boast about such things - that people are from all over Poland and even Europe. (Interview 1)

The experience of study abroad was perceived by some employers as something prestigious and was interpreted through the lens of the cosmopolitism, which provided returnees with a symbolic advantage as they make the institution more international. In international corporations non-institutionalised forms of cultural capital also acted as leverage. For Krystian, who returned to 'find a Polish wife' (Interview 2), his foreign diploma in law, his language skills and his knowledge of the international context helped him not only in finding a job but enabled him to consciously choose the nature and content of his future employment:

But I just came back with the idea not to work a lot, because I worked a lot [in England]. (...) And I thought I would be really chilled when it came to my future job. You know such a calm job in a corporation, it's cool. I also get along with people quite well so I'm good at it. A corporation is OK, I can handle it really well, and that's it and here I am. I first got to the complaints department and of course they really liked that I had been in England, that I knew the language and local customs.

Returnees' social capital was also significant when searching for an adequate job. However, here, the ties established during their migration appeared not to be as relevant as the primary links with family. Thus the successful translation of social capital into employment required emotional work and the maintenance of transnational relations with significant others. For example, once Tomek's wife became pregnant she wanted to return to Poland and Tomek - although he was very pleased with his job in the UK as a truck driver - went back with her. He used his family ties and, because of his experience of working abroad, it did not take him long to find employment. This is how he remembers his first job interview after returning to Poland:

A friend of my father's gave me the tip-off that there would be vacancies in a certain company and that I should try there. And I wrote my CV, in half an hour, it was terrible... I went there and they already had two piles with those resumés - one for those who were turned down and one for those to ask who sent you. So he looks at me... and the drivers there knew my father so I had it a lot easier, so to say. ((Tomek imitates the interviewer)) 'You are the son of this man, it's good... you were on the [British] island, you'll get along well in English, you won't have a problem somewhere abroad'. Well, that is how it started, because it was just my luck. (Interview 3)

The effortless transition between British and Polish labour markets depends on many factors. Nevertheless, possession of the sought-after skills appeared to be cru- 
cial in securing employment after return which, in turn, leads to the maintenance of a coherent career model. This model consists of a sequence of jobs that transcend the national borders yet are still related to each other in terms of the tasks and skills required or that are performed in the same sector of the economy. Moreover, the coherent careers are in line with migrants' expectations and typically they are situated in the relatively stable and well-paid segments of the labour market.

Importantly, this type of the transition is also effortless from the perspective of the state, which took a laissez-faire stance on returnees' integration. In the narratives of migrants who easily found satisfactory work on their return, the successful integration was perceived as a result of their personal merits, sometimes combined with a bit of luck. In the collected accounts the state institutions and policies played no role.

However, the withdrawal of the state strengthened effectively the disintegration of some other returnees, since the valuation and successful deployment of the different capitals possessed by them is largely limited by structural circumstances and the specificity of certain occupations, as will be shown in the next sections.

\subsubsection{The Unforseen Transition}

Characteristic for the unforseen type of transition is a career course other than that initially expected by the returnees. Despite their specific plans and ideas regarding a professional career in Poland, returnees encountered difficulties and eventually found employment - though not what they were expecting and in worse conditions than they had initially envisioned. Many migrants returned with the hope of professional advancement, which was supposed not only to compensate for their lower earnings - compared to those accessible to them in the UK - but also to be a sign of adult life. In terms of the sequence of events, migrants first returned and only later started looking for employment.

In the initial period after their return, migrants' accumulated savings also enabled them to be more picky regarding employment, as Anna, a 24-year-old waitress with a BA who was aiming for a managerial position, recalled:

Well, they called me, I don't think they liked it very much that I had some conditions, that I negotiated. I should beg them and kiss them and I don't know ... to get this job, and ... and finally I just said that the holidays had ended. (Interview 4)

Despite their higher ambitions and search for a job commensurate with their formal qualifications, some returnees could not find satisfactory employment. They explained that this was due to the extremely high competition and to job requirements which were impossible to meet. Women pointed also at gender discrimination, as Anna goes on to say:

I was supposed to be the deputy manager of a children's centre - you know, at these large, covered playgrounds. I even reached the second round of the recruitment but, unfortunately, in my opinion my fault was that I am 26 years old, so I will get pregnant right away, I will certainly give birth to four children and I won't work or something like that (ironically). 
Certainly, the age is a reason, that I am a woman is a reason. So they didn't call me and they still aren't calling.

Moreover, according to some narratives, the work experience from abroad was perceived either negatively as the returnees were deemed to now have higher financial demands, or at least irrelevant. As explained by Zofia, 31, a female quality controller holding an MSc:

You think it's going to be fantastic and how it [the labour experience from abroad] will open all doors for you, will break all ceilings. Well, it's not true because, in most places, they treat you as if you're just starting from scratch. It's as if, you know, 'You've been working somewhere abroad for a long time, but we don't care about it, it's different here', you know, that's how it works. (Interview 5)

Eventually, facing shrinking savings and unexpected expenditure, these returnees started searching for any job, lowering their expectations. This time, the work experience gained abroad - usually in services in the UK - appeared to be helpful in finding employment analogous in terms of job content and usually in catering or the hospitality sector. As explained by Krzysztof (29, M, hotel receptionist/student), 'It is true that maybe this experience abroad makes them choose your CV from the pile of other resumés, isn't it?' (Interview 6). Their new positions were characterised by the high work insecurity, a feature which they were already familiar with in the UK. This time, however, the unstable jobs were not compensated for by higher earnings, which often led to more general frustration, as was the case for 26-year-old freelance copywriter Maja (who has a degree):

So now it's OK, even though, after return to Poland, I lost hope. I was quite depressed since I didn't want to be a waitress. I knew that my references from England would certainly give me work in Poland, because I used to work there [in England] for Hilton and Marriott. (...) So they employed me very willingly and I must admit that, when I was looking for a job in Poland - between my fourth and fifth year of study - I finally decided to work in a hotel. I only chose where they pay better and where is closer to a place where I lived. (Interview 11)

In this way some returning migrants have fallen into the experience trap, which means the impossibility of obtaining the employment they wanted and being channelled instead, by the precarious work experience from abroad, into the sectors of the economy which the returnees wanted to leave behind. This process is particularly evident among those whose return was motivated by reasons not directly related to work - for instance, family reunion or breaking up with a partner in the UK. On the other hand the 'experience trap' might also turn into an 'experience path' - a situation whereby a low-skilled job, accepted unexpectedly and incompatible with the person's qualifications, turns into a passion developed back in Poland (cf. Grabowska 2016b).

Other aspects of the unforeseen transition underlined in the narratives are the insufficiency of social ties and the unexpected hostility of the state institutions, reflected for example by the attitude of civil servants. As a result of a stay abroad returnees redefine their perception of normality in the various areas of social life, including the functioning of the state and its institutions (Karolak 2016). Usually returnees have higher than before migration expectations towards the transparency of the state institutions, what ends with the 'harsh collision with reality', as described 
by Maja. Another interviewee, Kasia (27, F, a freelance musician with a BA) compares her experiences from Scotland and Poland:

You know what, [in Poland] it's not really about the employers. I'm a freelancer and I create a job for myself. So, it's more about the civil servants, I'm talking more about the civil servants who you can't reach if you don't know right people. And even if you get in, you have to 'market yourself' and you have to lie. (...) Scotland has changed me a lot. It created my vision of the world, tolerance, openness and gave me access, you know, to the support... to the whole social system, to all these benefits, the education system, subsidies for education. It was easy to communicate with police or social welfare authorities, well... The social welfare system, the social system in general, the system of society is a paradise in comparison with Poland. It is so easy to find oneself in it and.... and to feel part of it. (Interview 7)

Kasia's self-confidence and expectations regarding life in Poland have clashed with the reality. Although one cannot judge to what extent her skills fit labour market demand, it is undeniable that she feels disintegrated, mainly due to her weak social contacts, lack of credentials as well as lack of sufficient assistance of the state. Knowing 'the right people' appears to returnees to be crucial in a successful search for work in Poland. Moreover, many of them complain about the passivity and even hostility of the state institutions, which were supposed to support them. It needs to be noticed that the interviewees do not claim that they were discriminated because they were returning migrants, they rather have realised that the institutions could operate differently, what in some cases contributed to the 'feeling of being unwanted in Poland' and enhanced the disintegration process, as described in the next section.

\subsubsection{The Failed Transition}

The third type of transition refers to a failed one. It indicates a situation in which the returnee, despite attempts to find employment in Poland, eventually leaves the labour market and either decides to migrate yet again or becomes economically inactive. There is no one single reason for a failed transition since its generative mechanisms are very complex and include both structural and agential powers.

To better understand the difficulties faced by returnees, let us analyse in depth the case of Zofia, whom we met above, a 31-year-old woman from a town of 40,000 inhabitants. After graduating she made use of contacts in Wales and started working in a meat-processing plant. She was employed in accordance with her education as a quality controller; however, after 3 months she lost her job and the plant closed in the wake of the financial crisis. She found another job, also consistent with her education and experience, but needed to move 300 kilometres away. She felt isolated and concentrated mainly on her work, but she did not feel accepted by her colleagues. Finally, after two and half years spend abroad, Zofia stated:

I returned to Poland and decided to do this because it was supposed to be good, it was supposed to be so, uh... colourful and in general the work was supposed to be there, and it was supposed to be 'oh' and 'ah'. Because Europe is in crisis, but in Poland, nothing happens, supposedly nothing happens. (Interview 5) 
In terms of human capital, Zofia was well prepared to return. She did not experience skills mismatch, she had learned the technical language and gathered relevant experience in three different workplaces. Yet, she could not find a job that would satisfy her. Because she returned to her hometown, where there were few job opportunities, she considered moving to a bigger city. However, Zofia realised that the relationship between the wages offered and living costs, especially rent, were unacceptable:

The closest big city is 80 kilometres away, so to commute every day to work in which the earnings were so great (ironically) that the costs of commuting or cost of renting an apartment ... well, it was pointless. It was better to stay at home, really, and do nothing, because [working would be] doing something for nothing, since anyway you need to spend everything to, so to speak, survive, so you will end up with nothing. (Interview 5)

After a while she found a paid internship programme which guaranteed free accommodation. However, the programme was unexpectedly terminated and she needed to start looking for a job again. The following, longer excerpt from the interview with Zofia illustrates her hesitations and reflexive attempts to overcome the structural constraints:

And then it turned out again that you had to search for something, look for something, so I started looking for something and my sister said that maybe I would like to come to Warsaw and just live there. I thought about it, I admit frankly, that I thought about it, but... again the vision of moving, and then, I don't know what... It just wasn't fun for me. (...) but it was not only the vision of moving that was at stake. It was also about how old I was then -27 ? And I thought, OK, well, I would go to my sister, I would live with her, I would look for a job, but she has a husband, she has a child, I will find a job and then what? So will I live with her for the rest of my life? Well, while staying at my parents' home there was no other solution than to commute and still live with them. Because if you earn, I don't know, 1,500 zlotys gross ((ca.350 Euros)), it is quite hard to save anything, it's hard to do anything about it at all. (...) but at some point you just want to become independent, you know... And especially since I was always ... like I was always curious about the world. I wanted to be such a free spirit, independent... and I already was independent before, because I lived alone and I managed it very well and so coming back to my parents was a bit like a backward step. Apart from the fact that they are really great people and ... it's well known that nobody wants to live with their parents for the rest of their lives, no matter how wonderful they are. (...) So I started thinking about going abroad again, but I knew I didn't want to go back to Wales. (Interview 5)

Zofia's narration reveals several important aspects. First, although after return she did not have any relevant institutional support, she was not left alone with her problems in the labour market. Even with the anticipated low wages, she could count on help from her parents and sister. For precarious young workers in Poland, the support of the family often replaces that from the ineffective welfare state and became a common way of coping with the uncertainties of life (Karolak and Mrozowicki 2017). Moving back in with parents was a common practice among young returnees - nine of our interviewees had lived with their parents at one time or another after return. However, only those whose parents lived in major Polish cities with more job opportunities could take advantage of it. In the smaller towns, the need for independence from parents, in combination with the impossibility of 
paying all living costs from the offered wage, often leads to tensions and, in the end, re-emigration, perceived by young people as the only reasonable solution.

As noted by Cassarino (2004, p. 271), the situation of return migrants (also in the labour market) depends on 'the extent to which they have provided for the preparation of their return'. Preparation requires time, resources and willingness and ends in a certain level of readiness to return which, in turn, influences returnees' employment prospects. It is however also necessary to examine the structural situation in the country to which one returns. In Poland, structural constraints (the precarious work offered to young Poles, the high cost of city living, the lack of cheap and efficient public transport and exploitation during internships), together with workings of institutions confronted with returnees' expectations co-shaped by their previous experiences abroad, make some of them feel unwanted in and by their country of origin. It is well ilustrated in the narration of Agnieszka, a 26 years old cartographer, who after return to Poland opened with her husband a family busines, but after 2 years re-emigrated to the UK:

It was killing us, because we realised in what country we were living. We are two welleducated persons and we returned here [to Poland] from abroad with money. We bought a flat - a new one. We spent here a ton of money earned in another country, we established a company, the company was working, we paid taxes, we both wanted to work in this company, we want to have a child, supposedly there was a need for children in Poland and supposedly the pro-family policy should work. But it turned out, that on each of these paths ... in each of these sphere the state instead of encouraging us in any way... instead of saying in any way 'you are cool, you are young, ambitious, you want to have children and you even give work', we had an impression that they [the institutions] were bulling us in every possible situation and they were just trying to make it difficult for us ((laughs)). So we came to a very sad conclusions, that well, maybe the state doesn't want us to live here, it doesn't want us to earn money here, it doesn't want us to have children. (Interview 12)

Wheras the structural conditions make it impossible for some of returnees to successfully make use of their skills, also the returnees' subjective perception of 'being unwanted' by their country of origin contributes to their disintegration. It is not a deliberate mechanism; nevertheless, it de facto leads to the returnees' decision to leave Poland again (cf. White 2014). All in all, the facilitated intra-EU mobility and the individualised, transnational strategies employed by migrating workers effectively decrease the pressure on collective attempts to change the situation in their native land (cf. Meardi 2012).

\subsubsection{The Postponed Transition}

The final identified form of transition between the British and the Polish labour markets is the postponed transition. It refers to the situation in which a migrant who was economically active abroad but who, after return, did not even attempt to enter the Polish labour market and instead took a long break from employment. During this break from work, returnees typically re-entered or began academic education. Note that, of 11 cases in which return migrants undertake further education, six 
postponed their transition whereas five returnees studied and worked in Poland from the start.

This 'holiday from work' was possible because returnees' social income consisted of, on the one hand, their savings and, on the other, family support - typically accommodation but also financial transfer. As explained by Joanna who, at 36 and with an MA, was not working:

I had savings and later... I lived with my mother, so we... my mom helped, I had an apartment for free, etc. so there was no problem with that. So I could have calmly sacrificed myself... I don't hide the fact that I just took a holiday. I really rested, relaxed and, as I say, I worked on myself. (Interview 8)

Joanna, unlike Zofia, did not find it difficult to live with her mother. On the contrary, she perceived it as her duty to help her mother in a painful moment of divorce. Nevertheless, in other cases young returnees found themselves in an ambivalent situation, on the one hand being closer to the loving family, on the other suffering from the loss of economic independence, as put by Eryka, a 28-year-old female plant worker in Czechia who has an MA:

Interviewer: How did it happen that you decided to return and go to college?

Eryka: $\quad$ I mean, firstly, I missed my family; secondly, as I say ... my dad said that he won't keep a sponger at his home, so I have to go back to Poland and start studying. As long as my parents live and have the money, they'll educate me. (...) I was certainly happy that I came back, yes, especially to my mother, because I' $m$ very close to her. I' $m$ the youngest one. It certainly was... it was hard that I didn't have my money, yes, there was no money, so it wasn't like there [in the UK], when there was a payout every week, so every week you could go shopping. There was no such thing in Poland, it was also hard to find a job. (Interview 9)

Although inconvenient, returnees accepted this economic support, treating it as a temporary measure enabling them to improve their education, which eventually was supposed to help them to find employment in a primary segment of the labour market. From this perspective, the biographical experience of migration appears as trial adulthood, during which young people, within a biographical action scheme, experienced the mundane reality of life with jobs, taxes, incurrences as well as rented and usually shared apartments, but also could enjoy personal and economic freedom (cf. King et al. 2016). For them, return to Poland meant giving up all this and equalled a return to institutional patterns of expectation.

The question which arises is what happens to these returning migrants once they finish higher education. Do they remain on the occupational path and act like those graduates who have never migrated, or does the experience of life and work abroad still play a role in their decisions? To answer it exhaustively would require separate research focused on this particular type of transition; however a look at the six identified cases of postponed transition gives us a few hints already. After graduating, three of the participants migrated again, one to work in Czechia and commuting every day from Poland, the two others remaining in Poland, although they do not rule out the possibility of moving abroad. Asked why she decided to leave Poland after obtaining a brilliant BA degree from Jagiellonian University, Weronika (25, a tourist guide) answers: 


\begin{abstract}
Well, my reason was probably... it was financial, wasn't it? When we were in Cracow I studied, I worked. My boyfriend also studied in absentia and had a good position at work. I also had a good job. We earned good money, well, maybe normal. But in fact, with renting a flat, with travelling home, for example, every three months, etc., it wasn't enough to live on, was it? And it wasn't enough to start saving money for some future purposes, for some longer holidays, etc. So let's say that, by doing less here, whether in England or Scotland, we are earning more money and actually we can put this money aside for the future and we can visit more and so on... Well, I think that was my reason. (Interview 10)
\end{abstract}

For Weronika and her boyfriend, the re-migration was to enable them to achieve greater economic stability. From their perspective, they already had relatively good jobs in Poland but still felt that they could only live day-to-day, so migration appeared as an opportunity to make future plans. In this type of transition the role of the state and its institutions remained ambivalent. On the one hand the state gave those young returnees the opportunity to study for free. On the other hand, similarly to other types of transition, it did not provide any significant support, especially at the moment of transition from the school to work. This led to the situation in which the individual labour migration started replacing the role of the malfunctioning labour market institutions.

\title{
6.7 Conclusions
}

This chapter has discussed the labour market transitions and experiences of Polish migrants returning from the United Kingdom through the conceptual lens of (dis) integration. Analysis of the life stories of these mobile EU citizens revealed the heterogeneity of their career patterns. Contrary to the dominant discourse about spatial mobility being a career boost, supposedly contributing to upward mobility in society, return migration in many cases was linked with the fragmentation of careers and difficulties on the labour market.

After abandoning the rigid conceptual division between labour market integration and exclusion and employing the concept of the multi-segmented labour market, it became apparent that, although returnees usually found employment once back in Poland - and thus could be formally perceived as integrated in the labour market - the quality of their employment often deviated from their expectations and qualifications. Returning migrants often found themselves in vulnerable and precarious occupational positions, which highlights the fact that neither formal belonging nor experience from abroad can guarantee successful integration, the latter being always intertwined with certain processes of disintegration. The feeling of permanent temporariness while abroad as well as the feeling of 'being unwanted' and the 'experience trap' after return were recognised as relevant mechanisms contributing to the migrants' disintegration in Poland. Structural factors also turned out to be important, as they effectively hampered returnees' attempts to get the job they wanted. Note, however, that the structural constraints did not concern returnees as such but, rather, certain socio-economic groups to which the returnees belonged 
(sometimes simultaneously), be they youth, women or residents of small towns. What turned out to be specific for returnees, was their perception of the Polish state and its institutions as rather passive or in some cases even hostile. Although there is no evidence that such attitudes were aimed particularly against returning migrants it discouraged them from staying in Poland.

Nevertheless, there was a group of returnees who, after return, not only maintained their occupational status but also managed to climb the career ladder. They were able to actively manage, accumulate and exchange resources (most of all cultural and social capital) across borders, thus gaining an advantage on the Polish labour market. Importantly, analysis of their entire life stories revealed that the process of capital accumulation had already started before their migration, so they entered the UK with a decent knowledge of English and skills that were in demand. Moreover, the return of this group was usually directly related to work and was preceded by a search for employment from abroad.

The general conclusion which can be drawn from this chapter is that, in order to better understand the return migrants' labour market transitions, one should not consider the migration episode as an exclusive cause of returnees' positions in the labour market. Instead, the migration episode should be perceived as a catalyst or inhibitor of certain biographical trajectories deriving from the intersection of migrants' origins, gender, age, class, education as well as structural settings and politics of (dis)integration.

\section{Annex 1: Interviewees' Characteristics}

\begin{tabular}{l|l|l|l|l|l}
\hline Interview & Age & Gender & $\begin{array}{l}\text { Job or, if return migrating, last job } \\
\text { before leaving }\end{array}$ & Education & $\begin{array}{l}\text { Country of } \\
\text { residence }\end{array}$ \\
\hline 1 & 25 & Female & NGO employee & Tertiary (MA) & UK \\
\hline 2 & 28 & Male & Lawyer & Tertiary (MA) & Poland \\
\hline 3 & 30 & Male & Truck driver & $\begin{array}{l}\text { Secondary } \\
\text { technical }\end{array}$ & UK \\
\hline 4 & 25 & Female & Waitress & Tertiary (BA) & Poland \\
\hline 5 & 31 & Female & Quality controller & Tertiary (MSc) & UK \\
\hline 6 & 29 & Male & Hotel receptionist/student & Tertiary (BA) & Poland \\
\hline 7 & 29 & Female & Freelance musician & Tertiary (BA) & Poland \\
\hline 8 & 36 & Female & Economically inactive & Tertiary (MA) & Poland \\
\hline 9 & 28 & Female & Plant worker in Czechia & Tertiary (MA) & Poland \\
\hline 10 & 25 & Female & Tourist guide & Tertiary (MA) & UK \\
\hline 11 & 26 & Female & Freelance copywriter & Tertiary (MA) & Poland \\
\hline 12 & 26 & Female & Cartographer & Tertiary (BA) & UK \\
\hline
\end{tabular}




\section{References}

Ager, A., \& Strang, A. (2008). Understanding integration: A conceptual framework. Journal of Refugee Studies, 21(2), 166-191.

Anacka, M., \& Fihel, A. (2013). Charakterystyka migrantów powracających do polski oraz ich aktywność zawodowa na rodzimym rynku pracy. Studia Migracyjne - Przeglad Polonijny, 4, 57-71.

Bauman, Z. (2000). Liquid modernity. Cambridge: Polity Press.

Cassarino, J.-P. (2004). Theorising return migration: The conceptual approach to return migrants revisited. International Journal on Multicultural Societies, 6(2), 253-279.

Collyer, M., Hinger, S., \& Schweitzer, R. (2020). Politics of (dis)integration - An introduction. In S. Hinger \& R. Schweitzer (Eds.), Politics of (dis)integration (pp. 1-18). Cham: Springer VS.

Drinkwater, S., \& Garapich, M. P. (2013). Migration plans and strategies of recent polish migrants to England and Wales: Do they have any and how do they change? (Norface Discussion Paper Series No. 2013-23). London: NORFACE.

Durkheim, E. (1997 [1893]). Division of labour in society. New York: Free Press.

Eade, J., Drinkwater, S., \& Garapich, M. P. (2007). Class and ethnicity: Polish migrant workers in London (Full research report. ESRC end of award report, RES-000-22-1294). Swindon: ESRC.

Engbersen, G., \& Snel, E. (2013). Dynamic and fluid patterns of post-accession migration flows. In B. Glorius, I. Grabowska-Lusińska, \& A. Kuvik (Eds.), Mobility in transition. Migration patterns after EU enlargement (pp. 21-40). Amsterdam: Amsterdam University Press.

Engbersen, G., Snel, E., \& De Boom, J. (2010). "A Van full of poles": Liquid migration from central and Eastern Europe. In R. Black, G. Engbersen, M. Okólski, \& C. Pantîru (Eds.), A continent moving west?: EU Enlargement and labour migration from central and Eastern Europe (pp. 115-140). Amsterdam University Press.

Engbersen, G., Leerkes, A., Grabowska-Lusinska, I., Snel, E., \& Burgers, J. (2013). On the differential attachments of migrants from Central and Eastern Europe: A typology of labour migration. Journal of Ethnic and Migration Studies, 39(6), 959-981.

Faist, T. (2013). The mobility turn: A new paradigm for the social sciences? Ethnic and Racial Studies, 36(11), 1637-1646.

Fangen, K., Johansson, T., \& Hammarén, N. (2011). Young migrants: Exclusion and belonging in Europe. Basingstoke: Palgrave Macmillan.

Favell, A. (2008). The new face of east-west migration in Europe. Journal of Ethnic and Migration Studies, 34(5), 701-716.

Foucault, M. (2008). The birth of biopolitics: Lectures at the Collège de France, 1978-79. Basingstoke: Palgrave Macmillan.

Glaser, B., \& Strauss, A. (1967). The discovery of grounded theory: Strategies for qualitative research. Chicago: Aldine.

Grabowska, I. (2016a). The transition from education to employment abroad: The experiences of young people from Poland. Europe-Asia Studies, 68(8), 1421-1440.

Grabowska, I. (2016b). Movers and stayers: Social mobility, migration and skills. Frankfurt am Main: Peter Lang.

GUS. (2013). Migracje zagraniczne ludności. Narodowy Spis Powszechny Ludności i Mieszkań 2011. Warsaw: National Population and Housing Census 2011.

GUS. (2018). Informacja o rozmiarach i kierunkack czasowej emigracji z Polski w latach 20042017. Warsaw: Statistics Poland.

Hinger, S. (2020). Integration through disintegration? The distinction between deserving and undeserving refugees in national and local integration policies in Germany. In S. Hinger \& R. Schweitzer (Eds.), Politics of (dis)integration (pp. 19-39). Cham: Springer VS. 
Kaczmarczyk, P., \& Lesińska, M. (2012). Return migration, state policy and integration of returnees. In M. L. Butterworth (Ed.), Welcome home? Challenges and chances of return migration (pp. 29-37). Washington, DC: Transatlantic Forum on Migration and Integration.

Karolak, M. (2016). From potential to actual social remittances? Exploring how Polish return migrants cope with difficult employment conditions. Central and Eastern European Migration Review, 5(2), 21-39.

Karolak, M., \& Mrozowicki, A. (2017). Between normalisation and resistance. Life strategies of young precarious workers. Warsaw Forum of Economic Sociology, 1(15), 7-32.

Kaźmierska, K., Piotrowski, A., \& Waniek, K. (2011). Biographical consequences of working abroad in the context of European mental space construction. The Sociological Review, 60(1), $139-158$.

King, R., Lulle, A., Morosanu, L., \& Williams, A. (2016). International youth mobility and life transitions in Europe: Questions, definitions, typologies and theoretical approaches (Working Paper No. 86). Brighton: University of Sussex, Sussex Centre for Migration Research.

Lesińska, M. (2013). The dilemmas of policy towards return migration. The case of Poland after the EU accession. Central and Eastern European Migration Review, 2(1), 77-90.

Levitas, R. (2005). The inclusive society? Social exclusion and new labour. Basingstoke: Palgrave Macmillan.

Loveridge, R., \& Mok, A. (1979). Theories of labour market segmentation: A critique. The Hague: M. Nijhoff.

Meardi, G. (2012). Social failures of EU enlargement: A case of workers voting with their feet. London: Routledge.

Mezzadra, S., \& Neilson, B. (2013). Border as method, or the multiplication of labor. Durham/ London: Duke University Press.

Mrozowicki, A. (2011). Coping with social change: Life strategies of workers in Poland's new capitalism. Leuven: University Press Leuven.

Okólski, M. (2001). Incomplete migration: A new form of mobility in Central and Eastern Europe. The case of Polish and Ukrainian migrants. In C. Wallace \& D. Stola (Eds.), Patterns of migration in Central Europe (pp. 105-128). Basingstoke: Palgrave.

Polkowski, R. (2017). Normality unpacked: Migration, ethnicity and local structure of feeling among Polish migrant workers in Northern Ireland with a comparative perspective on Scotland. Journal of Ethnic and Migration Studies, 43(15), 2519-2535.

Potter, J. (2015). Crisis at work: Identity and the end of career. Basingstoke: Palgrave Macmillan.

Sahraoui, N., Polkowski, R., \& Karolak, M. (2018). Migration policies and their underlying threats: Going beyond the polarization of EU versus non-EU migration policies. In O. Fedyuk \& P. Stewart (Eds.), Inclusion and exclusion in Europe: Migration, work and employment perspectives (pp. 57-78). Colchester: ECPR Press.

Samuk, Ş. (2020). Can integration be temporary? The (dis)integration of temporary migrant workers in Canada and the UK. In S. Hinger \& R. Schweitzer (Eds.), Politics of (dis)integration (pp. 61-79). Cham: Springer VS.

Schütze, F. (2016). Biography analysis on the empirical base of autobiographical narratives: How to analyse autobiographical narrative interviews. In F. Schütze, W. Fiedler, \& H. Krüger (Eds.), Sozialwissenschaftliche Prozessanalyse: Grundlagen der qualitativen Sozialforschung (pp. 75-116). Opladen/Berlin/Toronto: Verlag Barbara Budrich.

Sennett, R. (1998). The corrosion of character: The personal consequences of work in the new capitalism. New York/London: W. W. Norton.

Sinatti, G. (2015). Return migration as a win-win-win scenario? Visions of return among Senegalese migrants, the state of origin and receiving countries. Ethnic and Racial Studies, $38(2), 275-291$.

Standing, G. (2011). The precariat: The new dangerous class. London: Bloomsbury Academic. 
Urry, J. (2000). Sociology beyond societies: Mobilities for the twenty-first century. London/New York: Routledge.

White, A. (2014). Polish return and double return migration. Europe-Asia Studies, 66(1), 25-49.

Wills, J., Datta, K., Evans, Y., Herbert, J., May, J., \& McIlwaine, C. (2010). Global cities at work: New migrant divisions of labour. New York: Pluto Press.

Open Access This chapter is licensed under the terms of the Creative Commons Attribution 4.0 International License (http://creativecommons.org/licenses/by/4.0/), which permits use, sharing, adaptation, distribution and reproduction in any medium or format, as long as you give appropriate credit to the original author(s) and the source, provide a link to the Creative Commons licence and indicate if changes were made.

The images or other third party material in this chapter are included in the chapter's Creative Commons licence, unless indicated otherwise in a credit line to the material. If material is not included in the chapter's Creative Commons licence and your intended use is not permitted by statutory regulation or exceeds the permitted use, you will need to obtain permission directly from the copyright holder. 